\title{
AZ ÖSZTÖNZÉS KÖVETKEZMÉNYEI A HAKNIGAZDASÁGBAN
}

Kerényi Péter ${ }^{1}$

\begin{abstract}
ABSZTRAKT
Folyamatosan terjed a világban a határozott idejü, szerződéses alapú foglalkoztatás. Ezt a munkaszervezési módot sok elnevezéssel illetik, mi a legátfogóbb értelemben a haknigazdaság (angolul gig economy) elnevezést használjuk a dolgozatban. Ismertetjük a haknigazdaság alapvető jellemzőit, különös tekintettel a munkás és a munkáltató viszonyát meghatározó, rövid távú és ösztönző szerződésekre. A haknigazdaságban a munkáltató teljesítménybérrel ösztönzi a munkást, hogy az a számára kedvező intenzitással dolgozzon. Az ösztönző teljesítménybérrel a munkáltató az üzleti kockázatát is kiszervezi a munkásnak, akinek ezáltal a bére és az egész munkája bizonytalan. A dolgozatban bemutatjuk, hogy a rövid távú ösztönző szerződésből eredeztethető bizonytalanság számtalan pszichológiai és társadalmi kihívás okozója.
\end{abstract}

JEL-kódok: Jo1, J31, J33, J38, J60, J81, J83

Kulcsszavak: haknigazdaság, önfoglalkoztatás, platformgazdaság, rugalmasság, ösztönzés, kockázat, bizonytalanság, prekaritás

\section{BEVEZETÉS}

Szemben a hagyományosnak tekinthető határozatlan idejü, hosszú távú foglalkoztatással, mind több munkavállaló dolgozik projektalapon határozott idejü, rövid távú szerződéssel. Katz-Krueger (2019) becslése szerint 2015-ben az Egyesült Államok munkaerőpiacán az alternatív munkarendben (határozott idejű szerződés, alkalmi munka, behívásos munkavégzés, nulla órás szerződés, szabadúszók) dolgozott a munkavállalók 15,8 százaléka, míg internetes közvetítőn keresztül dolgozott 0,5 százalékuk. Hasonlóan magas számokat közöl Európa 13 országából Huws et al. (2019), illetve Magyarországról Berde (2020). Ezt az egyre inkább terjedő, a hagyományostól eltérő munkaszervezési módot mind a magyar, mind pedig a nemzetközi szakirodalomban is több fogalommal azonosítják. Mi a legátfogóbb

1 Kerényi Péter PhD-hallgató, Budapesti Corvinus Egyetem Közgazdasági és Gazdaságinformatikai Doktori Iskola. E-mail: peter.kerenyi@uni-corvinus.hu. 
értelemben a haknigazdaság (angolul gig economy) elnevezést használjuk, és a későbbiekben érvelünk ezen magyar elnevezés mellett.

A 2. fejezetben áttekintjük a haknigazdaság hátterét: tisztázzuk, hogy mit is értünk pontosan haknigazdaság alatt, hogyan jellemezhető, és hogyan kapcsolódik ez a munkaszervezési mód olyan fogalmakhoz, mint közösségi gazdaság, applikációs munka, platformgazdaság, alkalmi munka, szabadúszás, önfoglalkoztatás, munkaerö-kölcsönzés stb. A haknigazdaság elsődleges hívószava a rugalmasság; a fejezet végén röviden vázoljuk, hogy milyen előnyökkel jár a rugalmasság a haknigazdaságban részt vevő fogyasztónak, munkáltatónak és munkásnak. Haknigazdaság-elemzésünk középpontjába a munkáltató és a munkás közötti kapcsolatot állítjuk. A 3. fejezetben a két fél kapcsolatát szerintünk alapjában meghatározó fogalmat, az ösztönző szerződést mutatjuk be. Ez az ösztönző szerződés, azaz teljesítményalapú bérezés az, ami megteremti a munkáltató számára a lehetőséget, hogy valóban kiaknázza a haknigazdaság rugalmasságát. Az ösztönzéssel viszont mindig párban jár a bizonytalanság és a kockázat is, ami elsősorban a haknimunkást sújtja. A 4. fejezetben a szakirodalom alapján áttekintjük a haknigazdaság pszichológiai és társadalmi kihívásait, amelyek az ösztönzés-kockázat központi motívumból következnek. Következtetéseinket az 5. fejezetben fogalmazzuk meg: minél inkább kiszolgáltatott egy munkás, annál inkább hatásos az ösztönzés, és egyre inkább úgy tűnik, hogy a haknigazdaság a rugalmasság álcája alatt a kiszolgáltatott tömegek kizsákmányolására épül. Elengedhetetlen a társadalom számára a haknigazdaság működésmódjának átgondolása és annak megfelelő szabályozása. Végül a 6. fejezetben röviden összefoglaljuk a dolgozat fő gondolatait.

\section{A HAKNIGAZDASÁG HÁTTERE}

A haknigazdaság egy olyan munkaszervezési, illetve foglalkoztatási mód, amelynek legfontosabb kritériumai, hogy a munkavállalók szerződéses alapon, határozott és általában rövid ideig, gyakori ismétléssel dolgoznak. A munkaszervezés sokszor online platformon keresztül zajlik. Sok szerző ezt az aspektust, az információt hatékonyan összegyüjtő és kezelő digitális platformot helyezi a középpontba, és ezen keresztül ragadja meg a jelenséget. Használják erre a foglalkoztatási formára a közösségi gazdaság (angolul crowdsourcing vagy crowdwork) elnevezést, utalva egyrészt arra, hogy a platform nagy dolgozói tömeggel áll kapcsolatban, másrészt arra, hogy a platform a hagyományos munkáltatói szerep számos feladatát és felelősségét kiszervezi (outsource) a munkásnak (pl. BergvallKåreborn-Howcroft, 2014). De elterjedt a platformgazdaság, a work-on-demand via app (pl. De Stefano, 2015) elnevezés, amit magyarul applikációs munkának 
vagy igény szerinti munkának fordíthatunk. Ezzel szemben azok, akik nem az online munkaszervezésre, hanem a rövid távú, ismétlődő szerződéses munkára fókuszálnak, leginkább a haknigazdaság elnevezést használják (pl. Ashford et al., 2018). Jelen dolgozatban mi is ebben a tágabb értelemben használjuk a haknigazdaság kifejezést. A mi megközelítésünk szerint a haknigazdaságban nem szükségszerü, hogy online platformon történjen a munkaszervezés, müködhet ez hagyományos közvetítőn keresztül is (pl. munkaerő-közvetítés, munkaerő-kölcsönzés), de az is előfordulhat, hogy a haknimunkás a munkaerejét közvetlenül értékesíti.

Na de pontosan kire is gondolunk, amikor egy haknimunkásról beszélünk? Azért, hogy jobban megértsük, hogyan is müködik (elméletben) ez a rugalmas munkaszervezési mód, a fenti értelmezés mentén lássunk röviden és leegyszerüsítve két példát! Klasszikus példa a haknimunkásra az applikáción keresztül érkező rendeléseket kiszállító, biciklis ételfutár (pl. Drahokoupil-Piasna, 2019; Goods et al., 2019; Gregory, 2020). A biciklis futár reggel eldönti, hogy aznap akar-e dolgozni, és ha igen, akkor mennyit és hol. Ezek alapján elteker a kiválasztott zónába, majd az applikáción keresztül bejelentkezik, és várja a megrendeléseket. Amint beérkezik az ajánlat, látja, hogy mi a pontos feladat, honnan hova kell szállítania az ételt, és azt is, hogy a szállításért cserébe mekkora összeget kap. Ezek alapján eldönti, hogy vállalja-e az adott fuvart, vagy sem. Amint úgy érzi, hogy elfáradt, és nem akar tovább dolgozni, akkor kilép az applikációból, ezzel jelzi, hogy ő nem fogad több ajánlatot. Amikor ismét dolgozni szeretne, akkor ismét belép az alkalmazásba, és jelzi, hogy várja az ajánlatokat. De nemcsak a biciklifutárhoz hasonló alacsony, hanem a magas képzettséget igénylő vagy kreatív munkakörökben is találkozhatunk haknimunkásokkal, bár ilyenkor a sokkal szebben hangzó szabadúszó kifejezést használják inkább. Erre lehet példa a grafikus, aki az egyik nap egy londoni pizzéria logóját tervezi meg, az utána lévő két hónapban egy amerikai vállalat teljes arculatának kialakításán dolgozik, esténként pedig a saját képregényét rajzolja. De számtalan más munkakörben is terjed ez a foglalkoztatási mód. Broughton et al. (2018) 150 haknimunkással (személy- és árufuvarozási, kreatív és magasan képzett, irodai adminisztrációs, alacsony képzettségű fizikai, valamint szakképzett fizikai munkákat végzőkkel) készült interjú alapján gyüjti össze a haknigazdaságban dolgozók motivációit és tapasztalatait.

A mi értelmezésünkben a haknigazdaságot a hagyományos foglalkoztatási formától megkülönböztető, fő jellemző a szerződéses munkaviszony, a szerződésben jól meghatározott foglalkoztatási idő és/vagy meghatározott feladat- és a teljesítményalapú ellentételezés, vagyis a (pénzügyi) ösztönzők (angolul incentives). A munkásnak vagy egy jól meghatározott feladatot kell megoldania minél gyorsabban, és/vagy egy meghatározott idő alatt kell minél több eredményt felmutatnia. A haknimunkás bére közvetlenül a megfigyelhető és ellenőrizhető teljesítmé- 
nyétől függ. A biciklis futár példájánál maradva, a bér attól függ, hogy mekkora utat tesz meg a munkaideje során. Leegyszerűsítve ezt az ösztönzőt, aki kétszer gyorsabban pedálozik, vagy aki egy nap kétszer annyi ideig van kint az utcán, az kétszer annyit is keres. Vagy az a grafikus, aki hétvégén is dolgozik, több projektet tud elvállalni, és így többet is keres.

A mi haknigazdaság-fogalmunk talán inkább a szabadúszás vagy önfoglalkoztatás fogalmakhoz, mint egyfajta vállalkozói tevékenységhez áll közel. Azért használjuk mégis a haknigazdaság kifejezést az előző fogalmakkal szemben, mert mind a szabad, mind pedig az ön szavak egyértelműen pozitív töltetűek, egyfajta szabad akaratra, önállóságra utalnak, miközben a korábban vázolt atipikus foglalkoztatási mód messze nem ilyen egyértelműen pozitív, és egyáltalán nem biztos, hogy például egy taxisoför Uberhez szegődése önálló döntés, és nem valamifajta gazdasági kényszer következménye. Erre utal a kényszervállalkozó (angolul forced entrepreneurship) és a hamis önfoglalkoztatás (angolul bogus self-employment) elnevezés is (MacDonald-Giazitzoglu, 2019), ezek viszont egyértelműen negatív töltetű szavak, amiket szintén erősnek éreznénk a jelenség megnevezésére. Ezek alapján, és egyetértve Gyulavári Tamással (Gyulavári, 2019) - aki a hakni szót az alkalmi, rövid ideig tartó munkavégzésre való utalása miatt javasolja - mi is a kissé pejoratív értelmü, eredetileg a művészeti előadói tevékenységre használt hakni kifejezéssel utalunk a dolgozatunk tárgyát képező munkaszervezési módra.

A haknigazdaságban a munkaszervezés különösen rugalmas, könnyen alkalmazkodik a változó igényekhez. A haknigazdaságot három típusú szereplőre, szerepkörre lehet osztani (pl. Stewart-Stanford, 2017; Broughton et al., 2018): a munkásra, a fogyasztóra és a közvetítőre. Megjegyezzük azonban, hogy a megengedő haknigazdaság-értelmezésünk szerint nem mindig beszélhetünk egyértelműen fogyasztói vagy közvetítői szereplőről, máskor pedig ez a két szerepkör egybemosódik. A munkás a munkaerejének felhasználásával elégíti ki a fogyasztó igényeit. A munkaszervező összegyűjti és feldolgozza a fogyasztási (munkakeresleti) és munkakínálati információkat, és ezek alapján szervezi a munkát. Annak ellenére, hogy tudjuk, a legtöbb országban a jog ezt a közvetítői tevékenységet nem munkáltatói jogviszonynak tekinti, mi ebben a dolgozatban az egyszerüség kedvéért mégis munkáltatónak nevezzük a munkaszervezési feladatot ellátó szereplőt. A haknigazdaság igazán a munkás és a munkáltató közötti viszonyban különbözik a hagyományos foglalkoztatástól, ezért dolgozatunk későbbi részeiben leginkább ezen két szereplő kapcsolatára és azon belül is az ösztönzés hatására összpontosítunk. 


\subsection{A fogyasztó}

A fogyasztó változó igényeihez alkalmazkodik a haknigazdaság, erre is utal például a sokak által használt igény szerinti munka (angolul on-demand job) elnevezés. A fogyasztói visszajelzés, a szolgáltatás minősége gyakran fontos szempontja a haknimunkás teljesítményalapú bérének, és ezért a fogyasztók magasabb minőségű szolgáltatáshoz juthatnak. A fogyasztók másik fontos szempontja az ár. Mivel a haknigazdaságban a munkáltatók a munkások nagy tömegével állnak kapcsolatban, így a verseny miatt a szolgáltatás ára is kedvező. Fogyasztóként ki ne örülne annak, ha az Uber megjelenésével a városában fele áron jutna ki a repülőtérre, mint annak előtte. A fogyasztó többletértékét a haknigazdaságban mutatja be Cachon és társai modellje is. A modell szerint a haknigazdaságnak a kereslet-kínálathoz való alkalmazkodása, a rugalmas munkaszervezés többletértéket eredményez a fogyasztónak a hagyományos foglalkoztatási móddal szemben (Cachon et al., 2017).

\subsection{A munkáltató}

A munkáltató, aki a munkát szervezi, az atipikus foglalkoztatás során számos olyan feladatot és kockázatot szervez ki, hárít át a munkásra, amit hagyományosan ő viselt. A munkás által megtermelt eredménytől függő teljesítménybér a fogyasztás és ezáltal a haknimunkák iránti kereslet ingadozásából fakadó bizonytalanságot a munkásra terheli. Ha a biciklis futárnak napi fix, a fuvarok számától független díjat kell fizetnie a platformba való bejelentkezésért cserébe, akkor a munkáltatónak közvetlenül nem okoz problémát egy-egy gyengébb forgalmú nap, mert annak a következménye, vagyis az alacsony forgalom utáni alacsony teljesítménybér a futárt sújtja. Persze, ha ez sokszor bekövetkezne, akkor egy idő után nem lenne munkás, aki kifizetné a fix díjat, így közvetetten a munkáltató is visel valamekkora kockázatot. Amíg azonban a munkáltató a munkások tömegét éri el, és mindig képes elegendő munkást bevonzani, addig ez a kockázat számára elenyésző mértékű. Egy érett szakaszban lévő, megfelelő menynyiségű információt összegyüjteni és kezelni képes munkáltató többletértéket ér el a haknigazdaságban a hagyományos foglalkoztatáshoz képest.

\subsection{A munkás}

A rugalmas munkavégzésnek, az önfoglalkoztatásnak több előnye is van a munkás szempontjából. A rugalmas munkaidő lehetőséget biztosít arra, hogy a munkás maga alakítsa ki a munka és a magánélete közötti egyensúlyt. A gyermekéről vagy idős hozzátartozójáról gondoskodó munkás számára nagy érték a hakni- 
gazdaság rugalmassága, hogy akkor vállal el egy-egy haknit, amikor erre ideje jut egyéb feladatai mellett. Az egyetemi diák tanulmányi kötelezettségei mellé jól beilleszthető az alkalmi munkavégzés. És van olyan haknimunkás, akinek fontos az a szabadság, az az autonómia, hogy maga irányíthatja a saját életét, saját munkáját és önmaga fönöke lehet. A rugalmasságon túl az is a haknigazdaság mellett szólhat, hogy a haknimunka jó keresetkiegészítés lehet, illetve az is igaz, hogy a jól teljesítő munkás magasabb bért is elérhet, mint a hagyományos formában foglalkoztatott társa. További előny lehet a pályakezdő fiatalnak, hogy a haknigazdaságban lehetősége van munkatapasztalatot szerezni, ami aztán a későbbiekben segítségére lehet a hagyományos értelemben vett munkájának a megszerzésében. A Broughton et al. (2018) kutatásában megszólított haknimunkások ezeket a szempontokat emelték ki, amikor a haknigazdaságban való részvételük motivációiról kérdezték őket (rugalmasság, jövedelem, munkatapasztalat).

\section{1. ábra}

A három szerepkör (fogyasztó, munkáltató, munkás) és a köztük lévő kapcsolatok sematikus ábrája

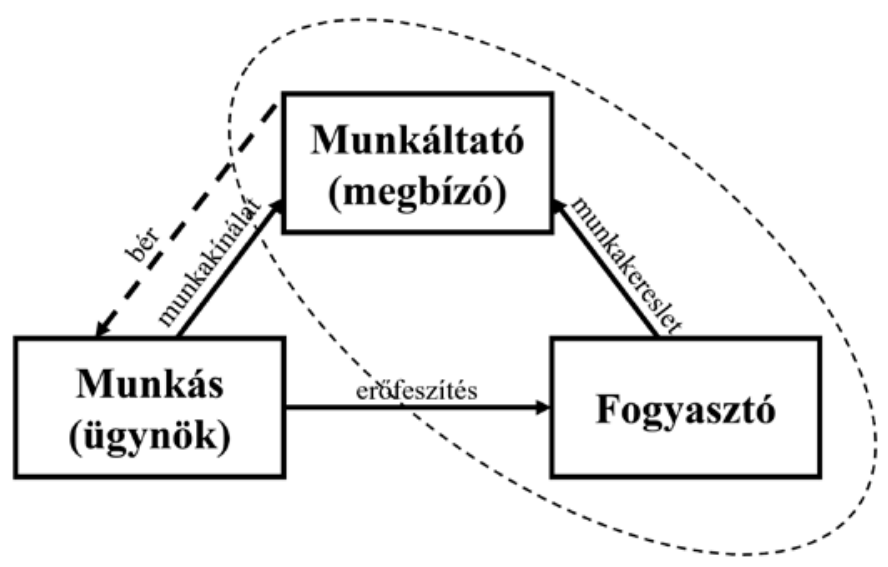

Forrás: saját szerkesztés

A megengedő haknigazdaság-értelmezésünk szerint nem mindig beszélhetünk egyértelműen fogyasztói vagy közvetítői szereplőről, máskor pedig ez a két szerepkör egybemosódik.

A fent összefoglalt szempontok alapján úgy tünik, hogy a rugalmas haknigazdaságban minden szereplő jól járhat. Hasonló következtetésre jut stilizált modellje alapján Cachon et al. (2017) is. A következő fejezetekben árnyaljuk majd ezt a hak- 
nigazdaságról eddig kialakított, pozitív képünket, és alaposabban átgondoljunk a munkás és a munkáltató viszonyát meghatározó ösztönző szerződést és az ebből fakadó, különböző egyéni és társadalmi problémákat.

\section{3. ÖSZTÖNZÉS ÉS KOCKÁZAT}

Az ösztönzés, vagy ahogy a köznyelvben is egyre többen használják, az inszentíva az utóbbi évtizedekben a munka világának egyik egyre markánsabb fogalma. Ez az ösztönzés minden esetben pénzügyi ösztönzést jelent, ami valójában nem más, mint a teljesítményalapú bér. Ebben a fejezetben a munkáltató és a munkás viszonyát meghatározó szerződéses mechanizmust mutatjuk be.

A munkáltató és a munkás közötti viszony és az ösztönzés szerepének megértéséhez egy alkalmas megközelítés a megbízó-ügynök modellkeret. Ez a modell Jensen és Meckling ügynökelméletéig vezethető vissza, akik a vállalat tulajdonosai és menedzserei közötti kapcsolat leírására használták:

„Az ügynökkapcsolatot mint egy szerződést definiáljuk, amelynek a keretében a megbízók nevében eljárva, az ügynökök használják az erőforrást. Mindez egyben azt is jelenti, hogy a döntéshozói jogkör is átkerül az ügynökök kezébe” (JensenMeckling, 1976:308). ${ }^{2}$

A megbízó az, aki elsősorban az erőforrás fölött rendelkezik, az ügynök pedig, aki használja az erőforrást, és erőfeszítést tesz. A mi haknigazdaság-értelmezésünkben a megbízó a munkáltató és az ügynök a munkás, az erőforrás pedig jellemzően az információ. A munkáltató átadja az erőforrást, a fogyasztói információkat a munkásnak, és megbízza, hogy ezek alapján elégítse ki a fogyasztó igényeit. Az átadott információ birtokában aztán a munkás dönt arról, hogy mikor és hogyan akarja felhasználni ezt az információt, és végrehajtani a megbízást. A biciklifutáros példában ez azt jelenti, hogy a munkáltató elküldi a munkásnak az információt, hogy mi az ügyfél megrendelése, honnan hova kell azt elszállítani, és megbízza, hogy ezt hajtsa végre. Innentől a munkás használja ezt az információt és dönti el, hogy mikor, merre és milyen gyorsan szállítja le a megrendelést.

\footnotetext{
2 A szerző fordítása.
} 


\section{1. táblázat}

\section{Néhány példa a munkásra és a munkáltatóra a haknigazdaságban}

\begin{tabular}{|c|c|c|}
\hline Munkás (ügynök) & Munkáltató (megbízó) & Tanulmányok \\
\hline ételfutár & $\begin{array}{l}\text { platform (pl. Netpincér GO, } \\
\text { Wolt, UberEATS, Deliveroo) }\end{array}$ & $\begin{array}{l}\text { Drahokoupil-Piasna } \\
\text { (2019); Goods et al. } \\
\text { (2019); Gregory (2020) }\end{array}$ \\
\hline személyfuvarozó & $\begin{array}{c}\text { platform (pl. Uber, Lyft, } \\
\text { Oszkár) }\end{array}$ & $\begin{array}{c}\text { Wu et al. (2019); } \\
\text { Berde-Kuncz (2020); } \\
\text { Berde-Tőkés (2020) }\end{array}$ \\
\hline stand-up komikus & $\begin{array}{l}\text { klubvezető, } \\
\text { rendezvényszervező }\end{array}$ & $\begin{array}{c}\text { Butler-Stoyanova Russel } \\
\text { (2018) }\end{array}$ \\
\hline $\begin{array}{l}\text { irodai } \\
\text { adminisztrátor }\end{array}$ & $\begin{array}{l}\text { platform (pl. Amazon } \\
\text { Mechanical Turk) }\end{array}$ & $\begin{array}{l}\text { Bergvall-Kåreborn- } \\
\text { Howcroft (2014) }\end{array}$ \\
\hline asztalos & platform (pl. TaskRabbit) & Prassl-Risak (2016) \\
\hline akadémiai kutató & egyetem, kutatóintézet & $\begin{array}{l}\text { Ivancheva (2015); } \\
\text { Loveday (2018) }\end{array}$ \\
\hline
\end{tabular}

Persze a munkáltató és a munkás érdekei, amelyek alapján előbbi vagy utóbbi a döntését meghozza, nem feltétlenül esnek egybe, ami érdekkonfliktushoz vezet. Ennek az érdekkonfliktusnak a feloldása az ösztönző szerződés. A munkáltató olyan szerződést ajánl a munkásnak, ami áttranszformálja a munkáltató érdekét a munkás szempontrendszerébe, és így végső soron a munkás is a munkáltató érdeke mentén fog dönteni. Mit jelent ez a biciklifutárunkra nézve? A munkáltató érdeke, hogy minél több megrendelést szállítson le a futár, azaz minél nagyobb erőfeszítéssel dolgozzon. A futár érdeke ezzel szemben az, hogy minél több pénzt keressen minél kisebb erőfeszítés, minél kevesebb tekerés árán. Ebből az átváltásból kialakul a munkáltató számára egy optimális, elvárt erőfeszítés, kívánatos tekerési intenzitás, amire szeretné rábírni a munkást. Ha a munkáltató képes közvetlenül megfigyelni a munkás erőfeszítését, azt, hogy milyen intenzitással teker, akkor ezt közvetlenül beleírhatja a szerződésbe. Ha a munkáltatónak az az érdeke, hogy a futár $25 \mathrm{~km} / \mathrm{h}$-val tekerjen, akkor olyan szerződést fog felajánlani, amiben az szerepel, hogy csak akkor kap bért a futár, ha ennél nagyobb a sebessége, ha ez alatt van, akkor pedig nem kap bért, hiába szállította le a megrendelést. Ezt a munkavégzés feletti közvetlen kontrollt a munkáltató első legjobb megoldásának nevezi a megbízó-ügynök szakirodalom. A haknigazdaságra jellemző, hogy a fejlett szenzorokkal, algoritmusokkal és fogyasztói értékelő rendszerekkel a munkáltató képes ellenőrizni a munkás erőfeszítését, de azért sok helyzetben erre a közvetlen kontrollra még sincs lehetősége. Ekkor a második legjobb megoldás 
az, ha a munkáltató a munka eredményéből - ami függ a munkás erőfeszítésétől - részesedést ajánl a munkásnak, így érdekeltté téve őt a komoly erőfeszítésben. Képlettel ezt egyszerüen úgy fogalmazhatjuk meg, hogy

bér $=$ fix bér + részesedés $\times$ eredmény.

Ha a fix bér nulla, akkor a munkás bére csak az eredménytől függ. Ha a fix bér pozitív, akkor a munkás az eredményalapú bér mellé egy attól független, biztos jövedelmet jelentő alapbért is kap. Ha a fix bér negatív, akkor a munkás egy rögzített bérleti díjat fizet a munkáltatónak az erőforrás használatáért, és ezért cserébe részesedést kap az eredményből. A munkáltató akár a munkából származó teljes bevételt is átengedheti a munkásnak a fix bérleti díjért cserébe. Ez a franchise és egyéb bérleti szerződésekhez hasonló struktúra, amikor a bérlő (a munkás) egy fix összegü royalty/bérleti díjat fizet az erőforrásért (pl. információ, know-how, eszköz) a tulajdonosnak, majd az üzletből származó profit pedig teljes egészében nála marad. Persze a fenti egyszerü lineáris (részesedésből és fix bérből álló) szerződésnél bonyolultabb struktúrák is lehetségesek, de a mi szempontunkból most az az elsődleges, hogy ilyenkor mindig valamilyen módon a munkás is arányosan (nem feltétlenül lineárisan) részesedik az erőfeszítésének az eredményéből.

A munkavégzés eredménye azonban nem egyértelmü függvénye a munkás erőfeszítésének, hanem egyéb, véletlen tényezők is befolyásolják. Mivel az eredmény nem csak a munkás erőfeszítésétől függ, így az is előfordulhat, hogy egy rossz napon, hiába tesz meg mindent és dolgozik keményen, rajta kívül álló okok miatt az eredmény és így az aznapi bére is alacsony lesz. Biciklis futárunk hiába áll egész nap a hideg esőben, és várja a megrendeléseket, ha aznap valami miatt a vásárlók mégsem rendelnek, azaz nincs kereslet a munkájára, akkor végeredményül nem keres semmit. A munkás kockázattal szembesül: nem garantált számára az, hogy egy adott erőfeszítés mellett mekkora biztos jövedelemre számíthat. A magasabb teljesítményre ösztönző részesedéssel nemcsak az eredmény, a gazdasági profit megfelelő aránya, hanem a kockázat egy része is átkerül a munkáltatótól a munkáshoz, vagyis a munkáltató az üzleti kockázatát is kiszervezi.

A haknigazdasággal foglalkozó irodalomban kevéssé hangsúlyosan jelenik meg az ösztönző szerződések bizonytalanságot befolyásoló szerepe. Kaine-Josserand (2019) szisztematikus irodalomfeldolgozása során 140 darab 2009 és 2019 között megjelent haknigazdasággal foglalkozó publikációt vizsgál. Szövegbányászati elemzésük során fogalomtérképet készítenek, és 69 kutatási témát azonosítanak, de ezek között nem szerepel az ösztönzés. Az általunk idézett, haknigazdasággal foglalkozó tanulmányokban szintén alig jelenik meg az ösztönzés koncepciója. A 2. táblázatban gyüjtöttük össze, hogy az általunk idézett tanulmányokban hányszor szerepel az ösztönzés kifejezés (incentiv- szótő). Ezen tanulmányok kö- 
zül mindössze Wu et al. (2019) foglalkozik hangsúlyosan az ösztönzéssel, a többi tanulmányban vagy alig vagy egyáltalán nem kerül elő a téma. A következő fejezetben mi az ösztönzés-kockázat megközelítésmódot visszük végig: a haknigazdaságra jellemző, ösztönző teljesítménybér és a vele együtt járó bizonytalanság egyéni és társadalmi következményeit mutatjuk be.

\section{2. táblázat}

A tanulmányban idézett, haknigazdasággal foglalkozó publikációk és a hozzájuk tartozó kulcsszavak*

\begin{tabular}{|c|c|c|c|}
\hline Tanulmány & Kulcsszavak & $\begin{array}{l}\text { Ösztönzés } \\
\text { szó }\end{array}$ & $\begin{array}{c}\text { Összes } \\
\text { szó }\end{array}$ \\
\hline Ashford et al. (2018) & N/A & 0 & 15322 \\
\hline Berde (2020) & N/A & 0 & 4626 \\
\hline Berde-Kuncz (2020) & $\begin{array}{l}\text { platformgazdaság, idősebb soförök, } \\
\text { online felmérés, játékelméleti modell }\end{array}$ & 0 & 4164 \\
\hline Berde-Tőkés (2020) & $\begin{array}{l}\text { utazásmegosztás, online platformokon } \\
\text { keresztüli munkakeresés, internetes } \\
\text { kattintások száma, idősebbek } \\
\text { foglalkoztatási rátája }\end{array}$ & 0 & 5243 \\
\hline $\begin{array}{l}\text { Bergvall-Kåreborn- } \\
\text { Howcroft (2014) }\end{array}$ & $\begin{array}{l}\text { Amazon Mechanical Turk, } \\
\text { crowdsourcing, digital labour, } \\
\text { outsourcing, platform, crowd } \\
\text { employment, ICT firms }\end{array}$ & 0 & 5649 \\
\hline Broughton et al. (2018) & N/A & 6 & 14183 \\
\hline $\begin{array}{l}\text { Butler-Stoyanova } \\
\text { Russel (2018) }\end{array}$ & $\begin{array}{l}\text { creative labour, emotional labour, } \\
\text { freelance work, precarity, } \\
\text { stand-up comedy }\end{array}$ & 2 & 9172 \\
\hline Cachon et al. (2017) & $\begin{array}{l}\text { self-scheduling capacity, peer-to-peer } \\
\text { markets, contract design, dynamic } \\
\text { pricing, service operations, ride sharing }\end{array}$ & 3 & 13799 \\
\hline De Stefano (2015) & N/A & 0 & 15843 \\
\hline $\begin{array}{l}\text { Drahokoupil-Piasna } \\
(2019)\end{array}$ & N/A & 6 & 11039 \\
\hline Friedman (2014) & $\begin{array}{l}\text { business fluctuations, labor economics, } \\
\text { labor policy, wage level and structure, } \\
\text { compensation packages, payment } \\
\text { methods, mobility, unemployment, } \\
\text { turnover, vacancies, } \\
\text { lay-offs, unemployment insurance }\end{array}$ & 2 & 7503 \\
\hline Goods et al. (2019) & $\begin{array}{l}\text { Gig economy, job quality, platform work, } \\
\text { post-Fordism, regulation }\end{array}$ & 2 & 9877 \\
\hline
\end{tabular}




\begin{tabular}{|c|c|c|c|}
\hline Tanulmány & Kulcsszavak & $\begin{array}{l}\text { Ösztönzés } \\
\text { szó }\end{array}$ & $\begin{array}{c}\text { Összes } \\
\text { szó }\end{array}$ \\
\hline Gregory (2020) & $\begin{array}{l}\text { gig economy, platform labour, } \\
\text { risk, self-employment }\end{array}$ & 1 & 6913 \\
\hline Gyulavári (2019) & N/A & 2 & 10629 \\
\hline Johnston et al. (2018) & N/A & 1 & 20313 \\
\hline Kaine-Josserand (2019) & $\begin{array}{l}\text { digital platforms, gig economy, gig work, } \\
\text { on-demand work, text mining }\end{array}$ & 5 & 7412 \\
\hline Katz-Krueger (2019) & $\begin{array}{l}\text { alternative work arrangements, } \\
\text { freelancers, } 1099 \text { economy, labor market } \\
\text { flexibility, temporary workers }\end{array}$ & 2 & 12788 \\
\hline Loveday (2018) & $\begin{array}{l}\text { anxiety, casualisation, governance, } \\
\text { higher education, neoliberalisation }\end{array}$ & 1 & 6871 \\
\hline $\begin{array}{l}\text { MacDonald- } \\
\text { Giazitzoglu (2019) }\end{array}$ & $\begin{array}{c}\text { enterprise, gig economy, insecurity, } \\
\text { precarity, self-employment, } \\
\text { Youth }<\text { Age groups }\end{array}$ & 0 & 6486 \\
\hline Petriglieri et al., 2019 & $\begin{array}{l}\text { work identity, emotion management, } \\
\text { holding environments, gig economy, } \\
\text { independent workers, systems } \\
\text { psychodynamics, individual agency }\end{array}$ & 0 & 19164 \\
\hline Prassl-Risak (2016) & N/A & 1 & 12761 \\
\hline $\begin{array}{l}\text { Stewart-Stanford } \\
(2017)\end{array}$ & $\begin{array}{l}\text { digital work, gig jobs, labour regulation, } \\
\text { precarity, risk }\end{array}$ & 0 & 6476 \\
\hline Wood (2018) & $\begin{array}{l}\text { discipline, flexibility, job insecurity, } \\
\text { labour process, scheduling, working } \\
\text { time, workplace control }\end{array}$ & 3 & 7208 \\
\hline Wood et al. (2019a) & $\begin{array}{l}\text { flexibility, gig economy, job quality, } \\
\text { labour process, platform economy, } \\
\text { workplace control }\end{array}$ & 0 & 7073 \\
\hline Wood et al. (2019b) & $\begin{array}{l}\text { commodification, digital labour, } \\
\text { embeddedness, freelancing, gig } \\
\text { economy, outsourcing, Polanyi }\end{array}$ & 3 & 7232 \\
\hline Wu et al. (2019) & $\begin{array}{l}\text { China, digital platform, gig work, } \\
\text { labor control, labor process }\end{array}$ & 24 & 9271 \\
\hline
\end{tabular}

Megjegyzés: *A tanulmányokban (cím, absztrakt és főszöveg) összesen hány szó van, és hányszor fordul elő az ösztönzés szó (angolul az incent-, magyarul pedig az ösztön- szótöredékre keresve). 


\section{KIHÍVÁSOK}

A haknigazdaság számos lehetőséget, de rengeteg új kihívást is tartogat, sokan egyenesen a munka új világáról beszélnek (pl. Beck, 2014; Ashford et al., 2018). A szerződésközpontúság miatt - ami az egyedi és folyamatosan megújuló, általában ösztönző szerződésekben ölt testet - a haknigazdaságban erős az individualizmus. Éppen ezért törekedtünk eddig arra, hogy a dolgozatban egyes számban beszéljünk a munkásról, ezzel is hangsúlyozva a haknigazdaság individualista, erősen egyénközpontú jellegét. Ebben a fejezetben a haknigazdaság azon kihívásaival foglalkozunk elsősorban, amelyek az ösztönzés-kockázat tandem következményei. Az egyénszintű problémákból indulunk ki, és így jutunk el a társadalmi és gazdasági kérdésekig.

A haknimunkásnak korábban nem megtapasztalt emocionális és pszichológiai nehézségekkel kell megküzdenie. Ashford et al. (2018) a haknigazdaság öt strukturális jellemzőjéből, (i) a pénzügyi instabilitásból és munkahelyi bizonytalanságból, (ii) az autonómiából, (iii) a karrierbizonytalanságból, (iv) a munka mulandóságából és (v) a fizikai és kapcsolati elkülönülésből határozza meg a haknimunkások előtt álló pszichológiai kihívásokat. MacDonald-Giazitzoglu (2019) többek között a haknimunkásokra jellemző, olyan vonásokat azonosít, mint a választás és az irányítás hiánya, a munka bizonytalansága, a jövedelem bizonytalansága, a kizsákmányolás, az önkizsákmányolás és a szorongás. Mi is a haknigazdaság fenti sajátosságait vesszük figyelembe elemzésünk során.

A szerződéses munkaviszony miatt a haknimunkás jövedelme bizonytalan, és ezért azt érzi, hogy állandóan a szakadék szélén táncol, folyamatos létbizonytalanságban él, szorong a jövő miatt, mert nem számíthat egy állandó, alapszintű, a mindennapi megélhetését biztosító jövedelemre. A teljesítménybér ráadásul erős versenyre is készteti, napról napra újra és újra meg kell küzdenie a munkáért. Ez a verseny az internetes jelleg miatt sokszor akár kontinenseken átívelő is lehet. Például egy londoni grafikus egy indiai grafikussal versenyez ugyanazért a munkáért, miközben a megélhetési költségek között sokszoros különbség van a két lokáció között, ami további feszültséget eredményez (Broughton et al., 2018). A verseny tovább fokozza a kommodifikáció jelenségét (Bergvall-Kåreborn-Howcroft, 2014; Wood et al., 2019b). A versenyben a munkások kevésbé kooperálnak és egyre inkább elidegenednek, eltávolodnak egymástól.

A haknimunkásnak nemcsak a jövedelme bizonytalan, hanem az egész munkája is. Soha nem lehet biztos abban, hogy az adott napon mit, hol és kivel fog dolgozni. A teljes munka identitása megkérdőjeleződik. Nincsenek munkahelyi kapcsolatai, és ezért magányos, ami rendkívül frusztráló számára (Petriglieri et al., 2019). A frusztráló magányban elidegenedik a munkájától, nem lojális sem a 
munkáltatójához, sem az ügyfeleihez, sem pedig saját társaihoz, és ezért nehezen képes a társaival való szolidaritásra.

A haknigazdaság ösztönzés narratívája azt sugallja, hogy a haknimunkás a maga szerencséjének a kovácsa, viszont ezért a munkás úgy érzi, hogy egyedül van, csak magára számíthat. Ez persze másrészről az előnye is a haknimunkának: a haknimunkás független, a maga ura, a maga fönöke és szabadon, rugalmasan alakítja a munkájának és magánéletének az egyensúlyát. Azonban sok haknimunkásnak talmi ez a függetlenség és szabadság. Ehhez a hamis szabadsághoz kapcsolódik a már korábban említett kényszervállalkozás (forced entrepreneurship) és a hamis önfoglalkoztatás (bogus self-employment) kifejezés. A munkás azt érzi, hogy valójában a munkáltató - ami sok esetben egy arctalan algoritmus képében jelentkezik (Wood et al., 2019a) - teljesen átveszi az irányítást az élete felett. És valóban, amint azt az előző fejezetben a megbízó-ügynök modellen keresztül bemutattuk, szabályozás hiányában az ösztönző szerződés formájában a munkáltató képes átvinni az akaratát, és kontrollálni a munkást (Wood, (2018); Wu et al., 2019). A korábban bemutatott biciklis futárunk is hiába akarna az egyetemi vizsgái miatt csak két órát dolgozni az adott napon - és tehetné meg ezt elméletben -, a valóság az, hogy a munkáltató céljai szerint megkonstruált ösztönző szerződés bünteti azt, ha valaki nem vállal legalább hatórás müszakot. A legtöbb haknimunkás elhúzódó műszakokról és a bérminimum alatti órabérről, előre nem látott kényszerekről számol be (Broughton et al., 2018). A szerződéseknek, gazdasági kényszereknek kiszolgáltatott, kizsákmányolt, sőt sokszor saját magát önkizsákmányoló haknimunkásnak a szabadság csak illúzió.

Hagyományos, határozatlan idejü foglalkoztatáskor, amikor egy munkás egy szervezeten belül dolgozik, akkor csak a saját feladatát, a saját munkáját kell ellátnia, az infrastruktúra üzemeltetésével, a termékek eladásával, az üzleti kockázattal nem a munkásnak kell foglalkoznia, ezt a szervezet megoldja a munkás elköteleződéséért és lojalitásáért cserébe. A haknimunkás idejének jelentős részét viszont éppen ilyen feladatok teszik ki: menedzseli a munkavégzéshez szükséges infrastruktúrát, folyamatosan újabb és újabb munkákat keres, reklámozza magát, egyszóval eladja saját magát (Ashford et al., 2018), ami ismét a kommodifikáció problematikáját veti fel. Ezek a munkájához nem közvetlenül kapcsolódó tevékenységek sok energiáját elveszik, ami csökkenti a termelékenységét. Emellett Friedman (2014) azt is megemlíti, hogy a haknimunkás a korábban felhalmozott humán tőkéjét fogyasztja el a munka során. Míg a hagyományos foglalkoztatásnál a munkáltató áldoz arra, hogy fejlessze a munkását, a haknigazdaságban ilyen humántőke-fejlesztés nem valósul meg. Míg a hagyományos, egy szervezet keretein belül dolgozó kollégák segítik egymást, működik a tudásátadás, ez a haknigazdaságból gyakorlatilag hiányzik. A munkáltatónak mindez mégis megéri, mert jórészt minden feladatát kiszervezte, és a saját költségeit és kockázatát 
csökkentette. Hiába csökken a termelékenység és a kibocsátás, a munkás kiszolgáltatottsága miatt a munkáltató mégis nagyobb szeletet kap az egyre csökkenő tortából.

Az ösztönző szerződéssel a munkáltató a kockázatot a munkásra hárítja. És éppen a kockázat az, amivel szemben az egyén a leginkább kiszolgáltatott. Egyéni szinten a kockázat, bizonytalanság nehezen megérthető, feldolgozható, kezelhető és beárazható. És erre a munkáltató sokszor rá is játszik, amikor úgy hirdeti a haknimunkákat, hogy azzal akár még ekkora és akkora jövedelemre is szert lehet tenni. A legoptimistább forgatókönyv szerinti maximálisan elérhető, rövid távú bérrel kecsegteti a munkást, nem pedig egy hosszú távon átlagosan elérhető, várható jövedelmet mutat be neki.

A haknigazdaság szinte mindenhol a világon alulszabályozott. A jog legtöbbször úgy tekint a haknimunkásra, mint független vállalkozóra, és azt feltételezi a munkáltatóval való viszonyáról, hogy abban két azonos alkuerővel rendelkező és egyenlő fél vesz részt. Éppen ezért a haknimunkásra nem vonatkoznak a foglalkoztatási szabályok, nincs korlátozva a munkaidő, a munkabér, nem jár neki védelem, fizetett szabadság és betegszabadság, nem jogosult nyugdíjra (StewartStanford, 2017; Broughton et al., 2018).

A haknigazdaság individualizmusa a munkás érdekérvényesítésének sem kedvez. A munkások önszerveződésének, érdekérvényesítésének és a szakszervezeteknek a lehetőségeiről ír Johnston et al. (2018). A kollektivizmus háttérbe szorulásával a munkások önszerveződése szinte lehetetlen, hiszen egyrészt a folyamatosan változó munka miatt legtöbbjüknek nincs kapcsolata a kollégáival - eleve az a fogalom, hogy kolléga, szinte értelmezhetetlen a haknigazdaságban. Másrészt a teljesítménybér sem arra ösztönzi a munkásokat, hogy egymással együttműködjenek. Kollektívizmus nélkül a haknimunkás alkuereje csekély az értékes erőforrás, az információ birtokában lévő munkáltatóval szemben.

\section{KÖVETKEZTETÉSEK}

Az előzőekben láttuk, hogy az ösztönző, rövid távú szerződések jelentős bizonytalanságot, kockázatot hárítanak a munkásra. És bár az igaz, hogy az általunk az előző fejezetekben vázolt haknigazdaságnak számtalan újszerü aspektusa van a hagyományos munkaszervezéshez képest - például az interneten keresztül történő információgyüjtés, feldolgozás és munkaszervezés -, de a szerződéses alapú, a kockázatot a munkásra hárító foglalkoztatás korántsem új találmány.

A mezőgazdaságban évszázados hagyománya van a szerződésalapú foglalkoztatásnak. A korábban bemutatott ösztönzés-kockázat mechanizmus alapján müködik a szakirodalomban angolul sharecroppingnak nevezett munkaszervezési 
forma (Stiglitz, 1974; Reid, 1975), amikor a föld tulajdonosa egy kis parcellát ad át (jellemzően egy évre) megművelésre a munkásnak egy fix bérleti díjért és/vagy a terményből való részesedésért cserébe. Az ösztönzés szerepének vizsgálatára jó példa Stiglitz (1974) Incentives and risk sharing in sharecropping című tanulmánya.

Magyarországon a földbérleti rendszer kevésbé terjedt el, de az ösztönzés-kockázat szempontjából ehhez nagyon hasonló volt a 18-19. században a részes aratás intézménye (Katona, 1961), amikor a munkás az általa betakarított terményből részesedett. Ehhez a részesmunka-fogalomhoz kapcsolódik még a szakmánymunka, az átaljás munka, a napszámosmunka és a summásmunka kifejezések is, amelyekről az Ortutay Gyula szerkesztette Magyar Néprajzi Lexikon (Ortutay, 1981) így ír:

„szakmánymunka, akkordmunka

a bérmunka egy fajtája, amikor a dolgozók (mezőgazdasági és ipari bérmunkás, a szakmányos) a kitermelt vagy feldolgozott anyag (fa, föld, szén, mezőgazdasági és ipari termék stb.) mennyisége után kapják előre meghatározott (rendszerint pénzbeli) fizetésüket. A mérés alapja lehet db. szám (pl. állatok nyírása), súly (morzsolás), terület (répaszedés), köbtartalom (kubik). A hagyományos részesmunkánál korszerübb, a hasonló átaljás munkánál pedig jóval ösztönzőbb; e kettővel együtt a teljesítménybéres munkák csoportjába tartozik, míg pl. a napszámosmunka időbéres, a summásmunka pedig vegyes típusú. (A szakirodalom mindezeket a fogalmakat nem használja egységes értelemben.)” (idézi Katona, 1981, félkövér kiemelés a szerzőtől).

Ezek az évszázadok óta működő foglalkoztatási módok teljesen beleillenek a mi haknigazdaság-fogalmunkba. A biciklis futár munkája jellegét tekintve megegyezik egy részes arató vagy egy napszámos munkájával. Aki kétszer olyan gyorsan teker a biciklin vagy kétszer olyan gyorsan szedi a gyümölcsöt, az kétszer annyi bért is kap. A haknigazdaság térnyerésével együtt nem meglepő módon a mezőgazdasági idény- és napszámosmunka aránya fokozatosan nőtt Magyarországon az elmúlt évtizedben (Hamar, 2016).

A haknigazdaság régi-új világa a kiszolgáltatott munkásokra épül. A haknigazdaság filozófiája szerint a munkaszerződés egyenlő felek között zajló tárgyalások eredményeként alakul. Ezzel szemben a valóságban a munkáltató az ösztönző szerződéssel, a teljesítménybérrel és a kockázat áthárításával kizsákmányolja azokat, akiknek csekély az alkuerejük, akik egyik napról a másikra élnek, akik hátrányos helyzetűek. Mert bár a haknigazdaság rugalmas, ez a rugalmasság föleg a munkás kárára a munkáltatónak kedvez. Ahogy MacDonald és Giazitzoglu fogalmaz, „ezeknek a munkásoknak a szempontjából a »rugalmasság« egy eufemizmus a kizsákmányolásra" (MacDonald-Giazitzoglu, 2019:733). Standing (2014) egy új társadalmi osztályt azonosít, amely tagjainak alapvető élménye a 
bizonytalanság, ezért ezt a társadalmi osztályt prekariátusnak nevezi. MacDonald-Giazitzoglu (2019) amellett érvel, hogy a haknigazdaság csak egy speciális példa a neoliberális, késő kapitalista társadalmakban már több évtizede jelen lévő prekaritás szélesebb körü és általánosabb jelenségére. A mi ösztönzés-kockázat megközelítésünk is ezt támasztja alá. ${ }^{3}$ Ahogy a korábbiakban mi is bemutattuk, a munkás számára a legtöbb probléma okozója a jövedelmének és munkájának a bizonytalansága, amit az ösztönző szerződés eredményez. A munkás kiszolgáltatott helyzete és alacsony érdekérvényesítő ereje miatt kénytelen belépni a haknigazdaságba, és rugalmasan alkalmazkodni, átvállalni a munkáltatótól szinte minden kockázatot. A haknimunkásnak alapvető érdeke, hogy valamifajta állandóságot csempésszen a folyamatosan változó haknigazdaságba, hogy csökkentse a kiszolgáltatottságát, és növelje a biztonságát.

Ahhoz, hogy a haknimunkások kiszolgáltatottságát csökkentsék, elengedhetetlen a munkakörülmények szabályozása, kezdve a korlátozott munkaidőtől a fizetett szabadságon és a bérminimumon át a munkanélküli támogatásig. Megfelelő munkajogi szabályozással és szociális ellátórendszerrel el lehet érni, hogy a munkások ne legyenek kénytelenek bármilyen kizsákmányoló feltételek mellett is elvállalni a haknimunkákat.

Stewart-Stanford (2017) a haknigazdaság szabályozásának lehetőségeit elemzi. A szerzők öt fö irányvonalat jelölnek ki: (i) a meglévő törvények érvényesítése, (ii) a foglalkoztatás meghatározásának pontosítása vagy kibővítése, (iii) a független munkavállaló új munkajogi kategóriájának létrehozása, (iii) a munkások (workers), nem pedig a munkavállalók (employees) jogainak megteremtése, illetve (iv) a munkáltató (employer) fogalmának átgondolása, felülvizsgálata. Tanulmányukkal arra buzdítják a szabályalkotókat, hogy bátran és ambiciózusabban nyúljanak a munkások jogait biztosító és védő elöírásokhoz.

\section{6. ÖSSZEGZÉS}

A dolgozatban bemutattuk az egyre bővülő haknigazdaság hátterét. Elemzésünk középpontjába a haknimunkás és a munkáltató viszonyát és az azt meghatározó ösztönző szerződést helyeztük. A korlátlatok nélküli, a munkás jogait figyelmen kívül hagyó, rövid távú szerződésekből következő ösztönzés-kockázat mechanizmust szemléltettük a megbízó-ügynök modell segítségével. Megnéztük, hogy a bizonytalanság, amit a szerződésen keresztül a munkáltató rákényszerít

3 Megjegyezzük, hogy STANDING (2011) megkülönbözteti a prekariátustól az egyéni vállalkozóknak és szabadúszóknak, szakembereknek (angolul proficians) nevezett osztályát, amelyek a mi haknigazdaság-fogalmunkban nem válnak ketté. 
a munkásra, valamint a túlzó individualizmus milyen pszichológiai és társadalmi kérdéseket vett fel. A haknigzadaság történelmi előképeit vizsgálva, mint a sharecropping vagy a mezőgazdasági napszámosmunka, arra jutottunk, hogy nem is annyira új, mint inkább régi-új a munkának ez a kiszolgáltatottságra építő, kizsákmányoló világa. A haknigazdaságot összekapcsoltuk a prekariátus társadalmi elméletével, és felvetettük a haknigazdaság szabályozásának, a haknimunkások jogainak fontosságát és szükségességét.

A szabadság és a rugalmasság hangzatos szólamai mögött a haknigazdaságban az ösztönzés valójában nem mást jelent, mint az üzleti kockázat kiszervezését, a munkások fölötti kontrollt és a munkaerő kizsákmányolását. A haknimunkásoknak akkor van a legjobb esélyük változtatni a helyzetükön, csökkenteni a kiszolgáltatottságot és növelni az alkuerejüket, ha sikerül elszakadniuk a haknigazdaság túlzóan individualista világától, és erősíteniük a kooperációt és a kollektivizmust.

\section{HIVATKOZÁSOK}

Ashford, Susan J. - Caza, Brianna. B. - Reid, Erin M. (2018): From surviving to thriving in the gig economy: A research agenda for individuals in the new world of work. Research in Organizational Behavior, 38, 23-41. https://doi.org/10.1016/j.riob.2018.11.0o1

BeCK, UlRICH (2014): The brave new world of work. Polity Press, Cambridge, UK. ISBN 0-7456-2397-2

BERDE Éva (2020): A sztenderd munkavégzés versus nem sztenderd munkavégzés. Új Munkaügyi Szemle, 1(1), 17-29.

Berde Éva - Kuncz Izabella (2020): Ha elmúlt ötvenöt éves, megmondja az életkorát? - Az Oszkár-soförök viselkedésének modellezése. Alkalmazott Matematikai Lapok, 37(2), 195-210. https://doi.org/10.37070/AML.2020.37.2.05.

Berde Éva - TőKÉs LÁszLó (2020): Platformokon keresztül dolgozó idősebb munkavállalók. Az Oszkár utazásmegosztó példája. Köz-Gazdaság, ONLINE FIRST, http://unipub.lib.unicorvinus.hu/4713/.

Bergvall-Kåreborn, Birgitta - Howcroft, Debra (2014): Amazon Mechanical Turk and the commodification of labour. New Technology, Work and Employment, 29(3), 213-223. https://doi. org/10.1111/ntwe.12038.

Broughton, Andrea - Gloster, Rosie - Marvell, Rosa - Green, Martha - Langley, Jamal - Martin, Alex (2018): The experiences of individuals in the gig economy. HM Government, Department for Business, Energy and Industrial Strategy. https://www.gov.uk/government/ publications/gig-economy-research.

Butler, Nick - Stoyanova Russell, Dimitrinka (2018): No funny business: Precarious work and emotional labour in stand-up comedy. Human Relations, 71(12), 1666-1686. https://doi. org/10.1177\%2Foo18726718758880.

Cachon, Gérard - Daniels, Kaitlin M. - Lobel, Ruben (2017): The role of surge pricing on a service platform with self-scheduling capacity. Manufacturing \& Service Operations Management, 19(3), 368-384. https://doi.org/10.1287/msom.2017.0618.

De Stefano, Valerio (2015): The rise of the just-in-time workforce: On-demand work, crowdwork, and labor protection in the gig-economy. Comp. Lab. L. \& Pol'y J., 37, 471-504. 
Drahokoupil, JAN - PiAsna, Agnieszka (2019): Work in the platform economy: Deliveroo riders in Belgium and the SMart arrangement. ETUI Research Paper-Working Paper. https://papers.ssrn. com/sol3/papers.cfm?abstract_id=3316133.

Friedman, Gerald (2014): Workers without employers: shadow corporations and the rise of the gig economy. Review of Keynesian Economics, 2(2), 171-188. https://doi.org/10.4337/roke.2014.02.03.

Goods, Caleb - Veen, Alex - Barratt, Tom (2019): “Is your gig any good?” Analysing job quality in the Australian platform-based food-delivery sector. Journal of Industrial Relations, 61(4), 502-527. https://doi.org/10.1177\%2Fo022185618817069.

Gregory, Karen (2020): 'My life is more valuable than this': Understanding risk among ondemand food couriers in Edinburgh. Work, Employment and Society, 35(2), 316-331. https://doi. org/10.1177\%2Fo950017020969593

Gyulavári TAmÁs (2019): Haknigazdaság a láthatáron: Az internetes munka fogalma és sajátosságai. Iustum Aequum Salutare, 15, 25-51.

Hamar AnNa (2016): Idénymunka a zöldség-gyümölcs ágazatban. In Kovács Katalin (szerk. 2016): Földből élők: Polarizáció a magyar vidéken. Budapest: Argumentum Kiadó, 93-111. ISBN 978-963-446-773-1.

Huws, Ursula - Spencer, Neil - Coates, Matthew - Sverre Syrdal, Dag - Holts, Kaire (2019): The platformisation of work in Europe: Results from research in 13 European countries. University of Hertfordshire. https://doi.org/10.18745/ds.216oo.

IVANCHEVA, MARIYA (2015): The age of precarity and the new challenges to the academic profession. Studia Universitatis Babes-Bolyai-Studia Europaea, 6o(1), 39-48.

Jensen, Michael C. - Meckling, William H. (1976): Theory of the firm: Managerial behavior, agency costs and ownership structure. Journal of Financial Economics, 3(4), 305-36o. https://doi. org/10.1016/0304-405X(76)90026-X.

Johnston, Hannah - LAnd-Kazlauskas, Chris (2018): Organizing on-demand: Representation, voice, and collective bargaining in the gig economy. Conditions of work and employment series, 94 .

Kaine, Sarah-Josserand, Emmanuel (2019): The organisation and experience of work in the gig economy. Journal of Industrial Relations, 61(4), 479-501. https://doi. org/10.1177\%2Foo22185619865480

Katona, ImRe (1961): Munkaszervezeti formák és ideiglenes életközösségek idénymunkákon a kapitalizmus korában. Agrártörténeti Szemle, 3-4, 534-562.

KAtona, ImRe (1981): szakmánymunka. In Ortutay Gyula (szerk. 1981): Magyar Néprajzi Lexikon IV. kötet. Budapest: Akadémiai Kiadó, ISBN 963-05-1289-0.

Katz, Lawrence. F. - Krueger, Alan. B. (2019): The rise and nature of alternative work arrangements in the United States, 1995-2015. ILR Review, 72(2), 382-416. https://doi. org/10.1177\%2Fo019793918820008.

Loveday, Vik (2018): The neurotic academic: Anxiety, casualisation, and governance in the neoliberalising university. Journal of Cultural Economy, 11(2), 154-166. https://doi.org/10.1080/ 17530350.2018.1426032

MacDonald, Robert - Giazitzoglu, Andreas (2019): Youth, enterprise and precarity: or, what is, and what is wrong with, the 'gig economy'? Journal of Sociology, 55(4), 724-740. https://doi. org/10.1177\%2F1440783319837604.

Ortutay Gyula (szerk., 1981): Magyar Néprajzi Lexikon IV. kötet. Budapest: Akadémiai Kiadó, ISBN 963-05-1289-0.

Petriglieri, Gianpiero - Ashford, Susan. J. - Wrzesniewski, Amy (2019): Agonyand ecstasyin the gig economy: Cultivating holding environments for precarious and personalized work identities. Administrative Science Quarterly, 64(1), 124-170. https://doi.org/10.1177\%2Fooo1839218759646. 
Prassl, Jeremias - Risak, Martin (2015): Uber, taskrabbit, and co.: Platforms as employersrethinking the legal analysis of crowdwork. Comp. Lab. L. \& Pol'y J., 37, 619-651.

Reid, Joseph D. (1975): Sharecropping in history and theory. Agricultural History, 49(2), 426-440. https://www.jstor.org/stable/3741281

Standing, Guy (2011): The Precariat - The new dangerous class. London: Bloomsbury Academic, ISBN 978-1-84966-352-6.

Stewart, Andrew - Stanford, Jim (2017): Regulating work in the gig economy: What are the options? The Economic and Labour Relations Review, 28(3), 420-437. https://doi. org/10.1177\%2F1035304617722461

Stiglitz, Joseph E. (1974): Incentives and risk sharing in sharecropping. The Review of Economic Studies, 41(2), 219-255. https://doi.org/10.2307/2296714.

Wood, Alex J. (2018): Powerful times: Flexible discipline and schedule gifts at work. Work, Employment and Society, 32(6), 1061-1077. https://doi.org/10.1177\%2F0950017017719839

Wood, Alex J. - Graham, Mark - Lehdonvirta, Vili - Hjorth, Isis (2019a): Good gig, bad gig: Autonomy and algorithmic control in the global gig economy. Work, Employment and Society, 33(1), 56-75. https://doi.org/10.1177\%2F0950017018785616.

Wood, Alex J. - Graham, Mark - Lehdonvirta, Vili - Hjorth, Isis (2019b): Networked but commodified: The (dis)embeddedness of digital labour in the gig economy. Sociology, 53(5), 931950. https://doi.org/10.1177\%2Foo38038519828906.

Wu, Qinguun - Zhang, Hao - Li, Zhen - Liu, Kai (2019): Labor control in the gig economy: Evidence from Uber in China. Journal of Industrial Relations, 61(4), 574-596. https://doi. org/10.1177\%2Foo22185619854472. 